\title{
CONTINUOUS AND CIRCULATED BATCH PROCESSES FOR ESTERIFICATION OF FREE FATTY ACIDS BY NOVOZYM 435 IN EXPANDED BED REACTOR: A CASE STUDY OF PALM FATTY ACID DISTILLATE
}

\section{SAWITTREE MULALEE*; BOONANUN SUMRANWONG* and MUENDUEN PHISALAPHONG*}

\begin{abstract}
An effective process for esterification of free fatty acids (FFA) by Novozym 435 in expanded bed reactors was developed. Oleic acid and palm fatty acid distillate (PFAD) were used as FFA. In the circulated batch process, Novozym 435 was reusable for 22 cycles with an FFA conversion greater than 90\%. Furthermore, in the continuous process using four expanded bed reactors connected in series, FFA conversions from the esterification of oleic acid and PFAD with a total residence time of $80 \mathrm{~min}$ were $93.5 \%$ and $88.5 \%$, with the overall productivity of about $1000 \mathrm{~g}$ and $940 \mathrm{~g}$ fatty acid methyl ester (FAME) litre $\mathrm{e} \mathrm{hr}^{-1}$, respectively.
\end{abstract}

Keywords: biodiesel, palm fatty acid distillate, esterification, expanded bed reactor.

Date received: 13 November 2017; Sent for revision: 16 December 2017; Accepted: 24 January 2019.

\section{INTRODUCTION}

Alternative and renewable fuels are widely explored and expected to ease fossil fuel demand. Among these alternative fuels, biodiesel is attractive because it is renewable, biodegradable and non-toxic. It can be blended with petroleum-based diesel due to its similar properties (Lee et al., 2010; Chongkhong et al., 2007). Biodiesel is produced from animal fats, vegetable oils, waste cooking oil or free fatty acids (FFA) (Chen et al., 2009; Fjerbaek et al., 2009) and alcohols using a transesterification or esterification process depending on the major feedstock of triglycerides or FFA. Methanol is the most widely used alcohol in biodiesel production attributed to its low cost and high reactivity compared to those of longer-chain alcohols with higher nucleophilicity and its lower steric hindrance than ethanol (Fjerbaek

\footnotetext{
Chemical Engineering Research Unit for Value Adding of Bioresources, Department of Chemical Engineering, Faculty of Engineering, Chulalongkorn University, Bangkok 10330, Thailand.

E-mail: muenduen.p@chula.ac.th
}

et al., 2009; Chongkhong et al., 2009; Zhao et al., 2014). Chemicals such as sulphuric acid $\left(\mathrm{H}_{2} \mathrm{SO}_{4}\right)$ and potassium hydroxide $(\mathrm{KOH})$ are widely used as catalysts for biodiesel production (Marchetti et al., 2007). However, enzymes are also potentially useful catalysts because they are compatible with several types of raw materials, reusable, energy efficient and produce less wastewater compared to processes using acid or base catalysts (Fjerbaek et al., 2009).

Novozym 435 is an interesting enzymatic catalyst for biodiesel production. Novozym 435 from Candida antarctica lipase $\mathrm{B}$, is produced by the submerged fermentation of Aspergillus microorganisms immobilised in a macroporous acrylic resin, and shows an effective performance compared to other immobilised lipases (Tamalampudi, 2008; José et al., 2013; Yang et al., 2014). Furthermore, Novozym 435 catalyses transesterification and esterification processes with mild operating conditions (Arroyo et al., 1999). Nevertheless, enzymatic biodiesel production is more expensive than those using chemical catalysts owing to the high price of enzymes (Chen et al., 2009). Therefore, 
improving the productivity of biodiesel and the reusability of enzymatic catalysts is important for commercialisation and industrialisation (Chen et al., 2011). Selection of the appropriate reactor type and operating conditions are major criteria for biodiesel production (Behzadi and Farid, 2009). Packed bed reactors have been extensively investigated for the use in industrial scale applications (Royon et al., 2007; Chen et al., 2009; Lee et al., 2010; Wang et al., 2011). The packed bed reactor is a widely used reactor for heterogeneous catalysis because the catalyst can be easily reused without separation from the reactor effluent. Besides, the mechanical shear stress that affects enzyme deactivation in a continuous stirredtank reactor can be prevented. Moreover, a packed bed reactor provides higher reaction performance (Chang et al., 2007; Chen et al., 2009; Fjerbaek et al., 2009) and lower operating costs than other batch processes.

Oleic acid is an unsaturated fatty acid that is the most widely distributed and abundant fatty acid in nature. It is monounsaturated fatty acid and is stable to thermal oxidation than many other unsaturated fatty acid components. Oleic acid is a major component in many low cost raw materials such as canola oil, palm oil, jatropha oil, rapeseed oil, soyabean oil, tallow and yellow grease (Anwar and Garforth, 2016). It has been used as a representative FFA in many studies on esterification.

In South-east Asia, biodiesel is produced from palm oil and its products is promoted as a renewable biofuel (Winayanuwattikun et al., 2008; Choo and Wafti, 2015; Pannilawithana and Pathirana, 2017). Palm fatty acid distillate (PFAD), a by-product of palm oil refineries and lower in cost than palm oil, is an alternative low cost feedstock for next generation palm biodiesel in South-east Asia (Chongkhong et al., 2009; Yujaroen et al., 2009). The esterification of PFAD can thus help reduce the production cost of biodiesel. Previously, esterification process for the production of biodiesel from PFAD has been developed using mild acid catalysts, i.e. sulphonic acids (Choo and Wafti, 2015). PFAD mainly consists of a mixture of FFA up to $93 \%-97 \%$ with a small percentage of mono-, di-, and triglycerides (Mulalee et al., 2015; Natthapon and Krit, 2015); therefore, at the same weight, PFAD can produce more biodiesel as compared to palm oil. Malaysia is one of the largest producers of palm oil and almost $700000 \mathrm{t} \mathrm{yr}^{-1}$ of PFAD were produced in Malaysia (MPOB, 2010). In January 2008-January 2010, the price difference between refined, bleached and deodourised (RBD) palm oil and PFAD is USD 100-USD $680 \mathrm{t}^{-1}$ (Cheah et al., 2010). According to the market price generated by collecting market price data from the Malaysian Palm Oil Board from January 2014 until May 2016, the average prices of RBD palm oil, olein, stearin and PFAD relative to crude palm oil (CPO) price was 105.0\%, 106.2\%, $99.6 \%$ and $92.1 \%$, respectively (Solikhah et al., 2017).
The present work aims to develop the esterification process of FFA (oleic acid and PFAD) and methanol using Novozym 435 as a biocatalyst from a batch process in our previous work (Mulalee et al., 2015) into circulated batch and continuous processes in expanded packed bed reactors. Important operating factors affecting FFA conversion, such as the feed volumetric flow rate, the amount of enzyme loading and the bed-to-catalyst volumetric ratio were investigated in a circulated batch process using a single packed/expanded bed reactor and then applied in the continuous process using multiple-expanded bed reactors connected in series. The efficiency of the enzymatic biodiesel production was evaluated.

\section{MATERIALS AND METHODS}

\section{Materials and Chemicals}

Novozym 435 (Lipase B from Candida antarctica, EC 3.1.1.3, a non-specific lipase immobilised on macroporous acrylic resin) was purchased from S M Chemical Supplies Co, Ltd (Bangkok, Thailand). The diameters of the particle beads were in the range of $0.3-0.9 \mathrm{~mm}$ with an approximate density of $0.4 \mathrm{~g} \mathrm{ml}^{-1}$. All other chemicals used in this work, oleic acid, methanol, $\mathrm{KOH}$ and phenolphthalein, were analytical grade and purchased from local suppliers in Thailand. PFAD was obtained from Patum Vegetable Oil Co. Ltd, Pathum Thani, Thailand.

\section{Circulated Batch Process Using Packed/Expanded Bed Reactor}

A cylindrical glass column with an inner radius of $2.5 \mathrm{~cm}$ and a height of $10.0 \mathrm{~cm}$ was used as the reactor. The total working volume of the reactor was $50-100 \mathrm{~cm}^{3}$. The bottom of the reactor $\left(\sim 40 \mathrm{~cm}^{3}\right)$ was used as a reservoir for stirring the feed mixture with a magnetic bar (No. 5) at $600 \mathrm{rpm}$ to homogenise the mixture. Novozym 435 was packed in a bed of an aluminum net covered with cotton fabric. The biocatalyst bed was packed inside the reactor. The optimal operating conditions for the esterification of oleic acid and alcohols by Novozym 435 from our previous study (Mulalee et al., 2015) were applied in this study. The reaction temperature was maintained at $45^{\circ} \mathrm{C}$, and the enzyme loading was $5 \% \mathrm{w} / \mathrm{w}$ of FFA. A mixture of $100 \mathrm{~g}$ of oleic acid and methanol at an FFA-to-alcohol molar ratio of 1:2 was thoroughly mixed and maintained at $45^{\circ} \mathrm{C}$ in a feed tank. The mixture was continuously fed into the reservoir of the reactor using a peristaltic pump at a constant flow rate. The mixture flowed upwards through the biocatalyst bed from the bottom to the top of the reactor, and the effluent was recycled into the agitated feed tank until the reaction reached equilibrium. 
The schematic diagram of esterification by Novozym 435 in the circulation batch process by packed/expanded bed reactors is shown in Figure 1. Figure 1a demonstrates a circulated batch expanded bed with volumetric ratio of bed to catalyst of 1:1 at enzyme loading of 5\% w/w of FFA. Figure $1 b$ demonstrates an expanded bed reactor with volumetric ratio of bed to catalyst of 2:1 at enzyme loading of $5 \% \mathrm{w} / \mathrm{w}$ of FFA. Figure $1 c$ demonstrates a doubly expanded bed reactor with volumetric ratio of bed to catalyst of 2:1 at enzyme loading of $10 \% \mathrm{w} / \mathrm{w}$ of FFA. The effluent was collected every hour to determine the FFA conversion. The effects of important factors such as volumetric flow rate, residence time and the amount of enzyme loading on the FFA conversion were investigated.

\section{Continuous Process Using Expanded Bed Reactors Connected in Series}

The circulated batch process described in the previous section was developed into a continuous process consisting of multiple expanded bed reactors connected in series, in which the effluent from the top of each reactor directly flowed into the bottom of the next one. The schematic diagram of continuous esterification of FFA and methanol by Novozym 435 in the expanded bed reactors connected in series is shown in Figure 2. When a steady state was reached, the effluent of each reactor was collected to determine the FFA conversion at each stage.

\section{Biodiesel Conversion Analysis}

The percentage of FFA conversion was determined by titration with $0.1 \mathrm{M} \mathrm{KOH}$ solution using phenolphthalein as the indicator. The FFA conversions were calculated from the titration volumes of the $\mathrm{KOH}$ solution (Mulalee et al., 2013). The reported values were the average values of each duplicate set. The titration was repeated three times for each sample and the data from each set had a small standard deviation (less than 1\%). From the experiments in the continuous operation, after the steady state, three samples were taken from each reactor for the analysis of FFA conversion. The

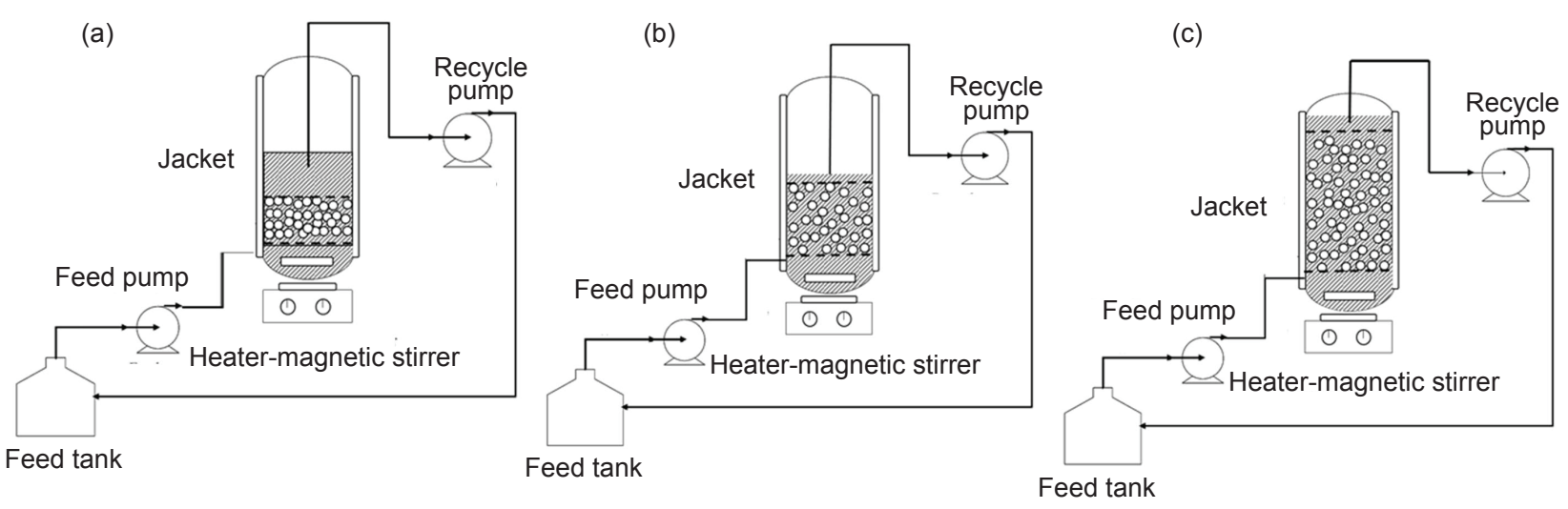

Figure 1. Schematic diagram of the esterification of free fatty acid (FFA) and methanol catalysed by Novozym 435 in the circulated batch process. (a) A packed bed reactor with volumetric ratio of bed to catalyst of 1:1, (b) an expanded bed reactor with volumetric ratio of bed to catalyst of 2:1 and, (c) a doubly expanded bed reactor with volumetric ratio of bed to catalyst of 2:1.

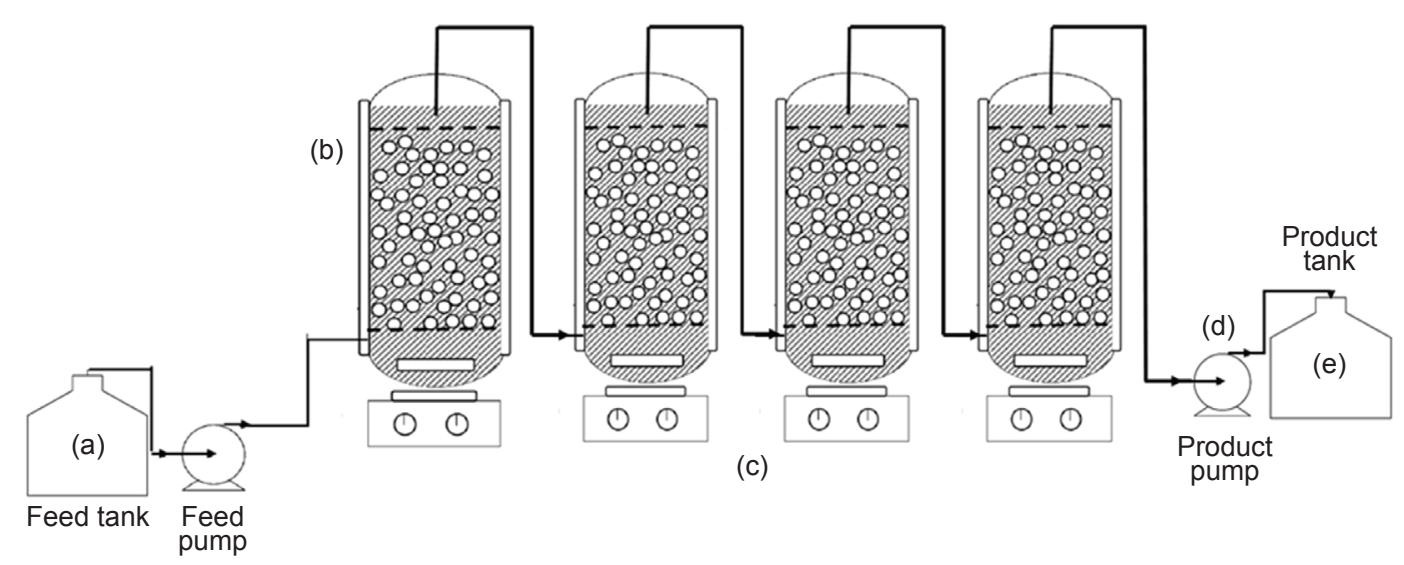

Figure 2. Schematic diagram of the esterification of free fatty acid (FFA) and methanol catalysed by Novozym 435 in the continuous process using four expanded bed reactors connected in series, consisting of a (a) feeding tank, (b) a multipleposition hot plate stirrer, (c) four expanded bed reactors connected in series, (d) peristaltic pumps, and (e) a product tank. 
calculation for FFA conversion from the titration method was calculated by the following equation (Chai et al., 2014).

$$
\text { FFA conversion }(\%)=\frac{(\text { Initial FFA }- \text { final FFA })}{\text { Initial FFA }} \times 100
$$

where, Initial FFA is initial acid value at time $t=$ $0\left(\mathrm{mg} \mathrm{KOH} \mathrm{g}^{-1}\right)$ and Final FFA is final acid value (mg $\left.\mathrm{KOH} \mathrm{g}^{-1}\right)$ at time $t=\mathrm{t}$.

The results were confirmed by the fatty acid methyl ester (FAME) yield analysed by nuclear magnetic resonance (NMR) spectroscopy (Varian Inova, $500 \mathrm{MHz}$, Lexington, MA, USA) (Tariq et al., 2011). The samples were sent to Research Instruments, Department of Chemistry, Faculty of Science, Chulalongkorn University for the determination of FAME conversion by NMR technique. The FAME yield was analysed by NMR $500 \mathrm{MHz}$ with CP/MAS solid probe and Nano probe (Varian version INOVA, Lexington, USA). NMR analysis was performed by dissolving the sample in $\mathrm{CDCl}_{3}$. The dissolved sample was transferred to a NMR tube. All solid material must be removed from the solution before it was placed in the NMR tube. Then, the NMR tube was inserted into a sample turbine. Spectra were recorded on a Varian Mercury-500 spectrometer operating at $500 \mathrm{MHz}$ at room temperature. The FAME content was determined by the ratio of the area of peaks associated with the methyl ester (3.65 ppm) and methylene group protons (2.26 ppm) (Hajar et al., 2009). The equation for FAME (\%) determination has shown below.

$$
\operatorname{FAME}(\%)=100 \times \frac{2 \mathrm{~A}_{\mathrm{Me}}}{3 \mathrm{~A}_{\mathrm{CH}_{2}}}
$$

where FAME (\%) is FAME yield of esterification; $\mathrm{A}_{\mathrm{Me}}$ is the integration value of the methoxy protons

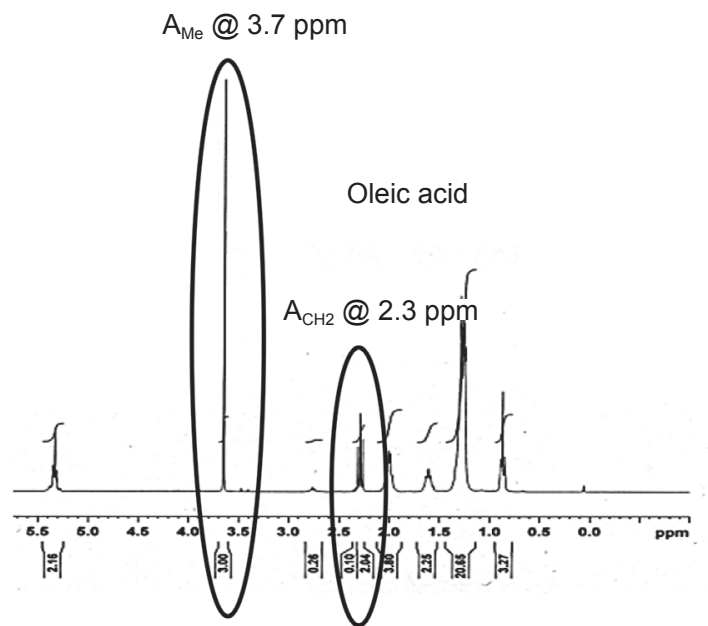

of the methyl esters, $\mathrm{A}_{\mathrm{CH}_{2}}$ is the integration value of $\alpha$-methylene protons and 2, 3 are proton numbers in the methylene and methoxy groups, respectively. Spectra analysed by NMR are shown in Figure 3.

According to the comparison between FFA conversion from the titration and FAME conversion from ${ }^{1} \mathrm{H}-\mathrm{NMR}$, we could confirm that the change of FFA was from the esterification reaction to convert FFA to FAME. The productivity was calculated based on the amount of FAME obtained $(\mathrm{g})$ from FFA conversion per reaction time (hr) per reactor volume (litre). Molecular weight (MW) of oleic acid and PFAD were 282.5 and 265.5, respectively (Natthapon and Krit, 2015). MW of methyl ester from oleic acid and PFAD were 296.5 and 279.5, respectively.

\section{RESULTS AND DISCUSSION}

\section{Circulated Batch Esterification of Oleic Acid Using a Packed/Expanded Bed Reactor}

Effect of feed volumetric flowrate on FFA conversion. The effect of feed volumetric flow rate ranging from 4-6 $\mathrm{ml} \mathrm{min}^{-1}$ on the FFA conversion in the packed bed reactor was investigated. The experiment was performed in a packed bed reactor under recycling flow of the effluent as shown in Figure 1a. The optimal operating conditions from our previous work (Mulalee et al., 2015) were applied as follows: reaction temperature of $45^{\circ} \mathrm{C}$, molar ratio of oleic acid to methanol at 1:2 and Novozym 435 loading at 5\% by weight of oleic acid. Figure $4 a$ shows the effect of the feed volumetric flow rate on the FFA conversion of oleic acid. The FFA conversion rate increased as the feed flow rate increased from $4-5 \mathrm{ml} \mathrm{min}^{-1}$ because the higher flow rate caused a higher external mass transfer rate (Chattopadhyay and Sen, 2013). The FFA conversion reached a maximum of $90.6 \%$ at a flow rate of $5 \mathrm{ml} \mathrm{min} \mathrm{mith}^{-1}$ with $8 \mathrm{hr}$. However, when the volumetric flow rate was increased from 5-6 ml min ${ }^{-1}$,

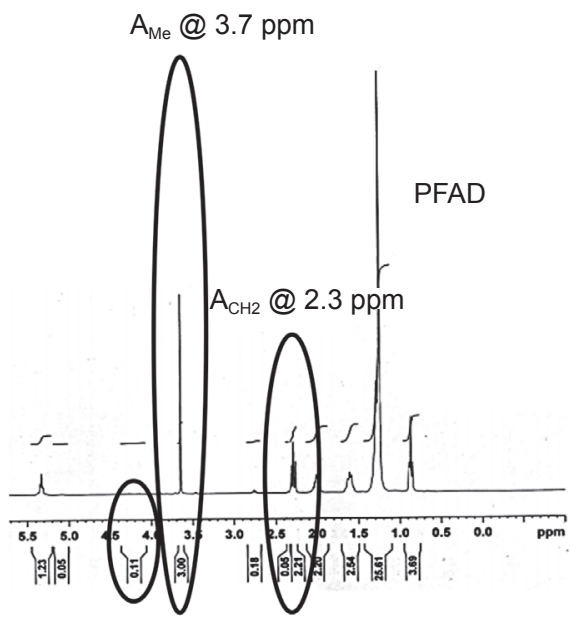

Figure 3. The H-nuclear magnetic resonance (NMR) spectra of fatty acid methyl ester (FAME) and free fatty acid (FFA) of esterification of oleic acid (left) and palm fatty acid distillate (PFAD) (right) with methanol catalysed by Novozym 435. 
the reaction rate decreased and the equilibrium time was extended from 8-9 hr. A similar effect of feed flow rate on FFA conversion has been observed previously in a study of the transesterification of vegetable oil in a packed bed reactor using immobilised lipase and a circulation process (Hajar et al., 2009; Lee et al., 2010). At a low flow rate, the FFA conversion was limited because of the mass transfer resistance at the liquid-film layer. However, at a high flow rate, the contact between the substrate and enzyme active sites was insufficient and could cause a low FAME yield (Halim et al., 2009). The shear stress of the high flow could also damage the immobilised biocatalyst (Wang et al., 2011).

Effect of volumetric ratio of bed to catalyst on FFA conversion. To study the effect of contact time of the reaction under the feed flow rate of $5 \mathrm{ml}$ $\mathrm{min}^{-1}$, the volumetric ratio of bed to biocatalyst was increased from 1:1 to 2:1 as shown in Figures $1 a$ and $1 b$ respectively. In this case, the reactor bed was expanded, the contact time in the bed was doubled, and the biocatalyst could move freely within the bed. This operation has the advantages of increased contact area and time between the substrate and catalyst. As shown in Figure $4 b$, the initial rate of esterification in the expanded bed with the volumetric ratio of bed to catalyst at 2:1 was higher than that in the bed with the $1: 1$ ratio. However, the equilibrium conversions of both systems were almost the same. Previously, an expanded bed reactor packed with active ionexchange resin catalyst was successfully developed for the continuous biodiesel production (ShibasakiKitakawa et al., 2007; 2010). As the expanded bed enhances the initial reaction rate, it was used for the following studies.

Effect of enzyme loading on FFA conversion. To improve the FFA conversion, the optimal enzyme loading for the reaction in the expanded bed was determined. In our previous batch study in 250-ml mixing flasks (Mulalee et al., 2015), the optimal enzyme loading of Novozym 435 was $5 \%$ w/w of FFA. Here, the enzyme loading in the expanded bed was increased to $10 \% \mathrm{w} / \mathrm{w}$ of FFA to observe the effect on the FFA conversion. The volumetric ratio of bed to biocatalyst was 2:1. A schematic diagram of the process is shown in Figure 1c. Figure 4c shows that when the enzyme loading was doubled from $5 \%$ to $10 \% \mathrm{w} / \mathrm{w}$ of FFA, the initial conversion rate and the equilibrium conversion were significantly enhanced. An FFA conversion of $96.7 \%$ was obtained using $10 \% \mathrm{w} / \mathrm{w}$ of Novozym 435 , which was about $7 \%$ higher than that obtained at $5 \% \mathrm{w} / \mathrm{w}$ of Novozym 435. Moreover, the equilibrium time was reduced from 7-8 hr to $5 \mathrm{hr}$. As the ratio between enzyme and substrates is higher in the expanded bed reactor compared with that in the batch reactor, a higher reaction performance was achieved (Chang et al.,
2007). The optimised reactor was then studied for reusability.
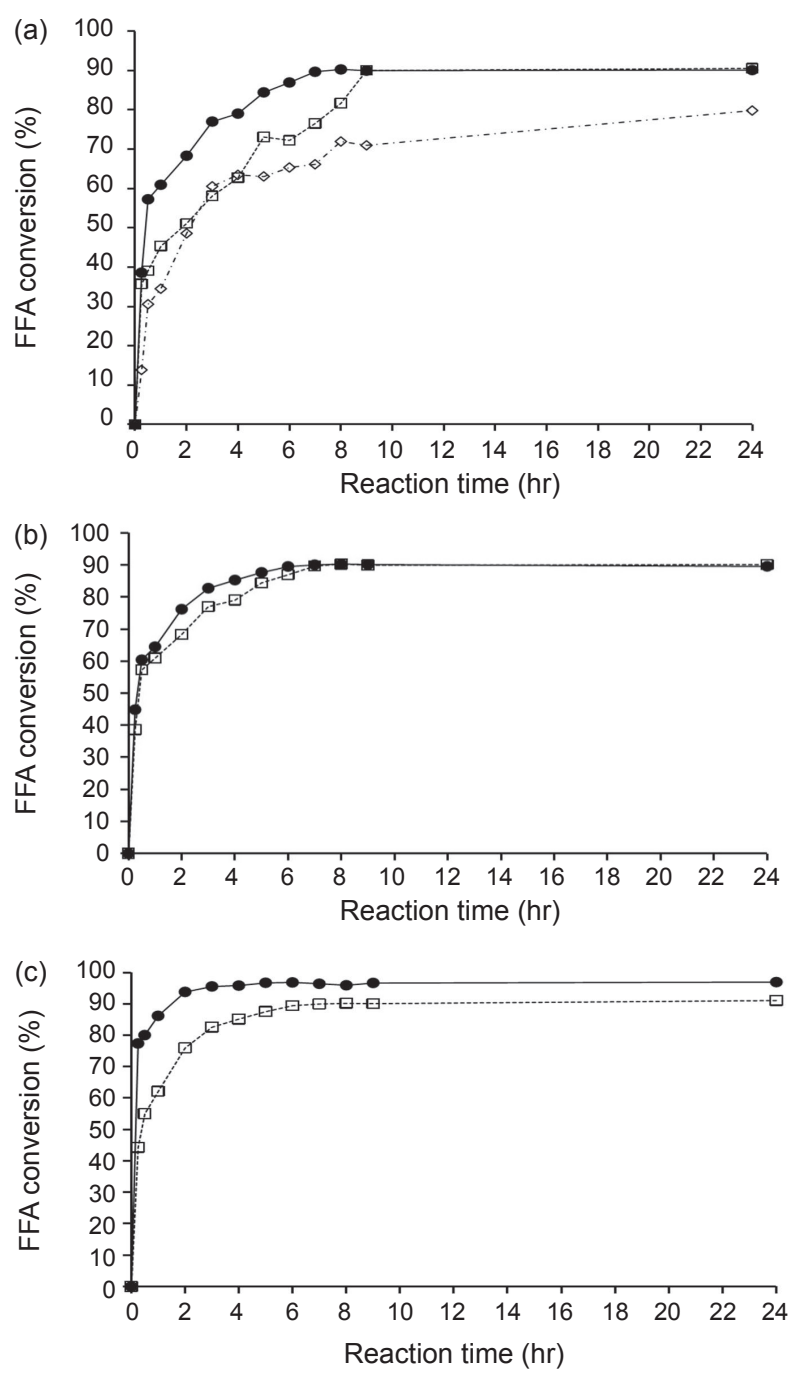

Figure 4. (a) Effect of flow rate on free fatty acid (FFA) conversion in a packed bed reactor: recycling flow rate of $4(\diamond), 5(\bullet)$ and $6(\square) \mathrm{ml} \mathrm{min}^{-1}$; (b) effect of volumetric ratio of bed to catalyst on FFA conversion in the circulated batch process: volumetric ratio of bed to catalyst of $1: 1$ (packed bed, ㅁ) and 2:1 (expanded bed, •); (c) effect of enzyme loading on FFA conversion in the circulated batch process using an expanded bed reactor at enzyme loading of 5\% (ㅁ) and 10\% (•) (w/w of FFA).

Reusability of Novozym 435 in the circulated batch process using an expanded bed reactor. For long-term operation and scale-up purposes, the reusability and stability of Novozym 435 in the single expanded bed reactor were investigated. Figure $5 a$ shows the reusability of Novozym 435 as a catalyst for the esterification reaction in the expanded bed reactor under the following conditions: $45^{\circ} \mathrm{C}$, FFA-tomethanol molar ratio of 1:2, enzyme loading at $10 \%$ $\mathrm{w} / \mathrm{w}$ of FFA, bed-to-catalyst volumetric ratio of 2:1

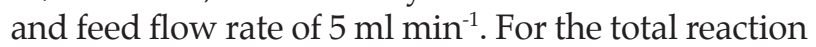
time in each batch of $5 \mathrm{hr}$, the FFA conversion could be maintained at greater than $90 \%$ for 22 cycles (110 $\mathrm{hr}$ ). This result demonstrates the higher efficiency and reusability of Novozym 435 as a biocatalyst in the circulated batch process using an expanded bed 
reactor compared with those of circulated batch processes in packed bed reactors (Hajar et al., 2009; Veny et al., 2014) and a repeated batch process in a shaking flask (Mulalee et al., 2015).

(a)

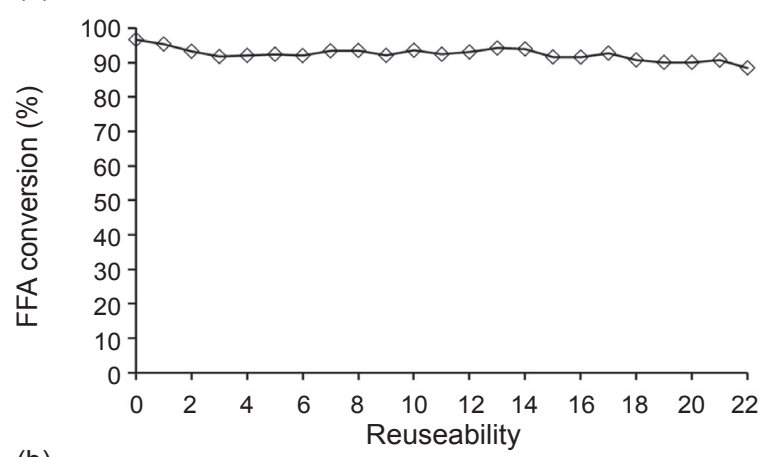

(b)

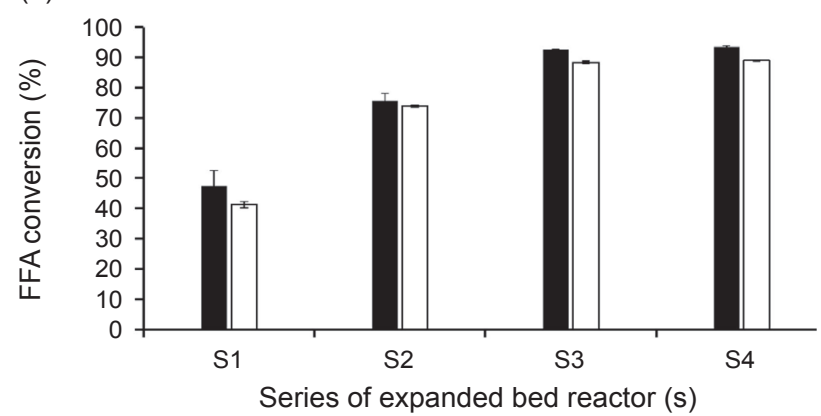

Figure 5. (a) Reusability of Novozym 435 on the esterification of oleic acid and methanol in the circulated batch process using an expanded bed reactor; (b) free fatty acid (FFA) conversion of oleic acid ( $\mathbf{\square}$ ) and palm fatty acid distillate (PFAD) ( $\square$ ) in the continuous process using four expanded bed reactors connected in series (values were expressed as mean $\pm S D, n=6$ ).

Continuous Esterification of Oleic Acid and PFAD Catalysed by Novozym 435 Using Expanded Bed Reactors Connected in Series

The continuous esterification process using four expanded bed reactors connected in series was developed to improve productivity and reduce operating time. The optimal operating conditions described in the previous section were used. The mean residence time in each reactor was $20 \mathrm{~min}$. The result from the continuous esterification of oleic acid with methanol catalysed by Novozym 435 in the four expanded bed reactors connected in series is shown in Figure 5b. The FFA conversions from the first, second, third and fourth reactors were $47.4 \%$, $75.6 \%, 92.6 \%$ and $93.5 \%$, respectively. Therefore, the number of expanded bed reactors required to reach equilibrium conversion was approximately four. Previously, an FFA conversion over $88 \%$ was maintained for $192 \mathrm{hr}$ in biodiesel production using a mixture of soyabean oil, distilled water, methanol and n-hexane, using four packed bed reactors connected in series that contained lipase- $\mathrm{Fe}_{3} \mathrm{O}_{4}$ nanoparticle biocomposites as the catalyst (Wang et al., 2011).
However, the residence time used in the packed bed reactors was about $10 \mathrm{hr}$, which is much longer than that in the expanded bed reactors used in this study (80 min). The overall productivity of biodiesel from the esterification of oleic acid was approximately $1000 \mathrm{~g}$ (FAME) litre $^{-1} \mathrm{hr}^{-1}$. The productivity of this process was considerably higher than those of the continuous processes using packed bed reactors previously reported (Chen et al., 2009; Wang et al., 2011; Chattopadhyay and Sen, 2012; 2013). However, other parameters such as differences in substrates, biocatalysts and operating conditions can also affect reaction performance (Silva et al., 2014). Compared with the systems using the same substrates catalysed by Novozym 435, the average productivity of the continuous process in four expanded bed reactors connected in series was about four times that of the circulated batch process in the expanded bed reactor and about six times that of the batch process in shake flasks (Mulalee et al., 2015). The comparison of transesterification and esterification studies was summarised as shown in Table 1.

Previously, the important parameters that affected the reusability of Novozyme 435 were temperature, type of alcohol, and water content (Mulalee et al., 2015). Therefore, it can be expected that the stability of Novozyme 435 in the expanded bed reactors connected in series operated under continuous mode should not be much difference from that of the expanded bed reactor under circulated batch operation. Nevertheless, for commercial exploitation, it is suggested that the stability of the expanded bed reactors connected in series operated under continuous mode should be further examined in detail before process scale-up.

The low cost feedstock PFAD was then applied for biodiesel production. The esterification of PFAD and methanol was catalysed by Novozym 435 in the continuous process of four expanded bed reactors connected in series under the previous optimal conditions. PFAD is a by-product obtained from the palm oil refining process in the edible oil industry. PFAD is an alternative low cost feedstock for next generation palm biodiesel in South-east Asia, with an emphasis on Indonesia, Malaysia and Thailand. PFAD contains FFA ( $93 \%$ ) with palmitic acid $(50.7 \%)$ and oleic acid $(41.0 \%)$ as major components (Mulalee et al., 2015). As shown in Figure 5b, the FFA conversion using PFAD as a feedstock was relatively lower than that using oleic acid. The FFA conversions from the first, second, third and fourth reactors were $41.2 \%$, $73.9 \%, 88.3 \%$ and $88.9 \%$, respectively. The final FFA conversion was about $5 \%$ lower than that using oleic acid as the FFA. The overall productivity of biodiesel from the esterification of PFAD was approximately $940 \mathrm{~g}$ FAME litre $^{-1} \mathrm{hr}^{-1}$. PFAD contains FFA and a small amount of unsaponifiable components and neutral oil. The process by-products include glycerol from the transesterification (Chongkhong et al., 2007; 
TABLE 1. COMPARISON OF TRANSESTERIFICATION AND ESTERIFICATION STUDIES

\begin{tabular}{|c|c|c|c|c|c|}
\hline Process & System information & $\begin{array}{c}\text { Free fatty acids } \\
\text { conversion }\end{array}$ & Reaction time & $\begin{array}{c}\text { Effective reactor } \\
\text { volume }\end{array}$ & Reference \\
\hline Packed-bed reactor & $\begin{array}{l}\text { Transesterification of } \\
\text { canola oil and methanol } \\
\text { at } 45^{\circ} \mathrm{C} \text { catalysed by } \\
\text { Novozym } 435\end{array}$ & $\begin{array}{l}97 \% \\
\text { (reusability for } \\
6 \text { batches) }\end{array}$ & $72 \mathrm{hr}$ & $\approx 40 \mathrm{~cm}^{3}$ & Hajar et al. (2009) \\
\hline $\begin{array}{l}\text { Circulated batch } \\
\text { packed bed }\end{array}$ & $\begin{array}{l}\text { Transesterification } \\
\text { of jatropha oil and } \\
\text { methanol at } 45^{\circ} \mathrm{C} \\
\text { catalysed by Lipozyme } \\
\text { IM }\end{array}$ & $\approx 85 \%$ & $8 \mathrm{hr}$ & $\approx 20 \mathrm{~cm}^{3}$ & Veny et al. (2014) \\
\hline Batch in shake flasks & & $\begin{array}{l}90.6 \%-94.8 \% \\
\text { (reusability for } \\
13 \text { batches) }\end{array}$ & $8 \mathrm{hr}$ & $150 \mathrm{~cm}^{3}$ & $\begin{array}{l}\text { Mulalee et al. } \\
(2015)\end{array}$ \\
\hline $\begin{array}{l}\text { Circulated batch } \\
\text { expanded bed }\end{array}$ & $\begin{array}{l}\text { Esterification of oleic } \\
\text { acid and methanol } \\
\text { at } 45^{\circ} \mathrm{C} \text { catalysed by } \\
\text { Novozym } 435\end{array}$ & $\begin{array}{l}90.1 \%-96.7 \% \\
\text { (reusability for } \\
22 \text { batches) }\end{array}$ & $5 \mathrm{hr}$ & $100 \mathrm{~cm}^{3}$ & This study \\
\hline $\begin{array}{l}\text { Continuous operation } \\
\text { in expanded bed }\end{array}$ & & $93.5 \%$ & $\begin{array}{c}80 \mathrm{~min} \\
\text { (for } 4 \text { in series) }\end{array}$ & $\begin{array}{c}200 \mathrm{~cm}^{3} \\
\left(50 \mathrm{~cm}^{3} / \text { reactor }\right)\end{array}$ & This study \\
\hline
\end{tabular}

Royon et al., 2007). Glycerol and other impurities from PFAD could absorb and coat the surface of Novozym 435. It was noticed that by using PFAD as a feedstock, the colour of the outer surface of Novozym 435 became darker with longer operating times. The coatings on the surface of Novozym 435 might lower the enzyme's activity (Royon et al., 2007). This problem might be avoided by the addition of a solvent such as acetone without significantly affecting enzyme activity (Chen et al., 2009).

\section{CONCLUSION}

Esterification of FFA by Novozym 435 with methanol in expanded bed reactor gave better conversion as compared to packed bed reactor. The optimal operating conditions for expanded bed reactors are as follows: FFA-to-methanol molar ratio of 1:2, $45^{\circ} \mathrm{C}$, feed flow rate of $5 \mathrm{ml} \mathrm{min}{ }^{-1}$, bed-to-catalyst volumetric ratio of 2:1, enzyme loading of $10 \%$ ( $\mathrm{w} / \mathrm{w}$ of FFA). In circulated batch expanded bed, FFA conversion greater than $90 \%$ could be achieved at a reaction time of $5 \mathrm{hr}$ with 22 cycles of reuse of Novozym 435 . Under continuous operation using four expanded bed reactors connected in series with a total residence time of $80 \mathrm{~min}$, FFA conversions from the esterification of oleic acid and PFAD were 93.5\% and $88.5 \%$, respectively. The overall productivities of biodiesel from the continuous esterification of oleic acid and PFAD were approximately four to six times those of batch processes. Therefore, the continuous operation in expanded bed represents a more costeffective method. Nevertheless, for commercial exploitation, it is suggested that the stability of the expanded bed reactors under continuous mode should be further examined in detail before process scale-up.

\section{ACKNOWLEDGEMENT}

We would like to thank the National Research Council of Thailand (NRCT) for financial support. We also received support from the $90^{\text {th }}$ anniversary of Chulalongkorn University (Ratchadaphiseksomphot Endowment Fund).

\section{REFERENCES}

Anwar, A and Garforth, A (2016). Challenges and opportunities of enhancing cold flow properties of biodiesel via heterogeneous catalysis. Fuel, 173: 189208.

Arroyo, M; Sa'Nchez-Montero, J M and Sinisterra, J V (1999). Thermal stabilization of immobilized lipase $\mathrm{B}$ from Candida antarctica on different supports: Effect of water activity on enzymatic activity in organic media. Enzyme Microb. Technol., 24: 3-12.

Behzadi, S and Farid, M M (2009). Production of biodiesel using a continuous gas-liquid reactor. Bioresour. Technol., 100: 683-689.

Chai, M; Tu, Q; Lu, M and Yang, Y J (2014). Esterification pretreatment of free fatty acid in biodiesel production from laboratory to industry. Fuel Process. Technol., 125: 106-113. 
Chang, S W; Shaw, J F; Yang, C K and Shieh, C J (2007). Optimal continuous biosynthesis of hexyl laurate by a packed bed bioreactor. Process Biochem., 42: 1362-1366.

Chattopadhyay, S and Sen, R (2013). Development of a novel integrated continuous reactor system for biocatalytic production of biodiesel. Bioresour. Technol., 147: 395-400.

Chattopadhyay, S and Sen, R (2012). A comparative performance evaluation of jute and eggshell matrices to immobilize pancreatic lipase. Process Biochem., 47: 749-757.

Cheah, K Y; Toh, T S and Koh, P M (2010). Palm fatty acid distillate biodiesel: Next-generation palm biodiesel. Inform Vol. 21(5): 264-266. https:/ / www.aocs.org/stay-informed/inform-magazine/ featured-articles / palm-fatty-acid-distillatebiodiesel-next-generation-palm-biodieselmay-2010, accessed on 28 December 2019.

Chen, H C; Ju, H Y; Wu, T T; Liu, Y C; Lee, C C; Chang, C; Chung, Y L and Shieh, C J (2011). Continuous production of lipase-catalyzed biodiesel in a packed-bed reactor: Optimization and enzyme reuse study. J. Biomed. Biotechnol., 2011: 1-6.

Chen, Y; Xiao, B; Chang, J; Fu, Y; Lv, P and Wang, X (2009). Synthesis of biodiesel from waste cooking oil using immobilized lipase in fixed bed reactor. Energ. Convers. Manage., 50: 668-673.

Chongkhong, S; Tongurai, C and Chetpattananondh, $P$ (2009). Continuous esterification for biodiesel production from palm fatty acid distillate using economical process. Renew. Energ., 34: 1059-1063.

Chongkhong, S; Tongurai, C; Chetpattananondh, P and Bunyakan, C (2007). Biodiesel production by esterification of palm fatty acid distillate. Biomass Bioener., 31: 563-568.

Choo, Y M and Wafti, N S A (2015). Production technology of biodiesel from palm fatty acid distillate using mild acid catalyst. J. Oil Palm Res. Vol. 27: 352-359.

Fjerbaek, L; Christensen, K V and Norddahl, B (2009). A review of the current state of biodiesel production using enzymatic transesterification. Biotechnol. Bioeng., 102: 1298-1315.

Hajar, M; Shokrollahzadeh, S; Vahabzadeh, F and Monazzami, A (2009). Solvent-free methanolysis of canola oil in a packed-bed reactor with use of Novozym 435 plus loofa. Enzyme Microb. Tech., 45: 188-194.
Halim, S F A; Kamaruddin, A H and Fernando, W J N (2009). Continuous biosynthesis of biodiesel from waste cooking palm oil in a packed bed reactor: Optimization using response surface methodology (RSM) and mass transfer studies. Bioresour. Technol., 100: 710-716.

José, C; Austic, G B; Bonetto, R D; Burton, R M and Briand, L E (2013). Investigation of the stability of Novozym ${ }^{\circledR} 435$ in the production of biodiesel. Catal. Today., 213: 73-80.

Lee, J H; Kim, S B; Park, C; Tae, B; Han, SO and Kim, S W (2010). Development of batch and continuous processes on biodiesel production in a packed-bed reactor by a mixture of immobilized Candida rugosa and Rhizopus oryzae lipases. Appl. Biochem. Biotech., 161: 365-371.

Marchetti, J M; Miguel, V U and Errazu, A F (2007). Possible methods for biodiesel production. Renew. Sust. Energ. Rev., 11: 1300-1311.

Mulalee, S; Srisuwan, P and Phisalaphong, M (2015). Influences of operating conditions on biocatalytic activity and reusability of Novozym 435 for esterification of free fatty acids with short-chain alcohols: A case study of palm fatty acid distillate. Chinese J. Chem. Eng., 23: 1851-1856.

Mulalee, S; Chanprasert, J; Kerdpoksup, P; Sawangpanya, N and Phisalaphong, M (2013). Esterification of oleic acid and bioalcohols using immobilized lipase. Adv. Mat. Res., 724-725: 11541157.

Natthapon, S and Krit, S (2015). Optimization of methyl ester production from palm fatty acid distrllate using single-step esterification: A response surface methodology approach. ARPN J. Eng, Appl. Sci, 10: 7075-7079.

Pannilawithana, N A and Pathirana, H M K K (2017). A green method to produce biodiesel from palm olein oil. J. Oil Palm Res. Vol. 29(1): 67-77.

Royon, D; Daz, M; Ellenrieder, G and Locatelli, S (2007). Enzymatic production of biodiesel from cotton seed oil using t-butanol as a solvent. Bioresour. Technol., 98: 648-653.

Shibasaki-Kitakawa, N; Tsuji, T; Chida, K; Kubo, $\mathrm{M}$ and Yonemoto, T (2010). Simple continuous production process of biodiesel fuel from oil with high content of free fatty acid using ion-exchange resin catalysts. Energ. Fuel., 24: 3634-3638.

Shibasaki-Kitakawa, N; Honda, H; Kuribayashi, $\mathrm{H}$; Toda, T; Fukumura, $\mathrm{T}$ and Yonemoto, $\mathrm{T}$ 
(2007). Biodiesel production using anionic ionexchange resin as heterogeneous catalyst. Bioresour. Technol., 98: 416-421.

Silva, W C E; Teixeira, L F; Carvalho, A K F; Mendes, A A and De Castro, H F (2014). Influence of feedstock source on the biocatalyst stability and reactor performance in continuous biodiesel production. $J$. Ind. Eng. Chem., 20: 881-886.

Solikhah, M D; Kismanto, A; Raksodewanto, A and Peryoga, Y (2017). Profitibility and sustainability of small-medium scale palm biodiesel plant. Green process, material and energy: A sustainable solution for climate change. Proc. of the $3^{\text {rd }}$ International Conference on Engineering, Technology, and Industrial Application (ICETIA 2016). Surakarta, Indonesia. p. 1-8.

Tamalampudi, S; Talukder, M R; Hama, S; Numata, T; Kondo, A and Fukuda, H (2008). Enzymatic production of biodiesel from jatropha oil: A comparative study of immobilized-whole cell and commercial lipases as a biocatalyst. Biochem. Eng. J., 39: 185-189.

Tariq, M; Ali, S; Ahmad, F; Ahmad, M; Zafar, M; Khalid, N and Khan, M A (2011). Identification, FTIR, NMR (1H and 13C) and GC/MS studies of fatty acid methyl esters in biodiesel from rocket seed oil. Fuel Process. Technol., 92: 336-341.

Veny, H; Aroua, M K and Sulaiman, N M N (2014). Kinetic study of lipase catalyzed transesterification of jatropha oil in circulated batch packed bed reactor. Chem. Eng. J., 237: 123-130.

Wang, X; Liu, X; Zhao, C; Ding, Y and Xu, P (2011). Biodiesel production in packed-bed reactors using lipase-nanoparticle biocomposite. Bioresour. Technol., 102: 6352-6355.

Winayanuwattikun, P; Kaewpiboon, C; Piriyakananona, K; Tantonga, S; Thakernkarnkita, W; Chulalaksananukulb, W and Yongvanicha, $\mathrm{T}$ (2008). Potential plant oil feedstock for lipasecatalyzed biodiesel production in Thailand. Biomass Bioener., 32: 1279-1286.

Yang, K; Bi, Y; Sun, S; Yang, G and $\mathrm{Ma}$, $S$ (2014). Optimisation of Novozym-435catalysed esterification of fatty acid mixture for the preparation of medium- and long-chain triglycerides (MLCT) in solvent-free medium. Int. J. Food Sci. Tech., 49: 1001-1011.

Yujaroen, D; Goto, M; Sasaki, M and Shotipruk, A (2009). Esterification of palm fatty acid distillate (PFAD) in supercritical methanol: Effect of hydrolysis on reaction reactivity. Fuel, 88: 2011-2016.

Zhao, H; Liu, J; L V, F; Ye, R; Bie, $\mathrm{X}$ and Zhang, C (2014). Enzymatic synthesis of lard-based ascorbyl esters in a packed-bed reactor: Optimization by response surface methodology and evaluation of antioxidant properties. LWT - Food Sci. Technol., 57: 393-399. 